\title{
Potential of Adipose-Derived Stem Cells for Regeneration Medicine: Clinical Application and Usefulness of Fat Grafting
}

Natsuko Kakudo*, Naoki Morimoto, Takeshi Ogawa and Kenji Kusumoto

Department of Plastic and Reconstructive Surgery, Kansai Medical University, Osaka, Japan

\begin{abstract}
Adipose-derived stem cells (ASCs) have the same multipotency as bone marrow mesenchymal stem cells. Thus, adipose tissue substitutes for bone marrow as a source of stem cells. Ideally, a method to isolate and differentiate ASCs should be established, and adipose tissue should be utilized as a source of stem cells for regenerative medicine. Manual and automatic stem cell separation procedures are employed to separate ASCs from adipose tissue. In this chapter, we describe the potential of adipose-derived stem cells for regeneration medicine: clinical application and usefulness of fat grafting.
\end{abstract}

\section{Introduction}

Subcutaneous adipose tissue has recently been attracting attention as a new cell source for regenerative medicine, replacing bone marrow. Among fibroblast-like cells, termed adipose stromal cells, stromalvascular cells, and preadipocytes, cells with potency to differentiate into not only adipocytes and blood vessels but also various lineages are present [1], and they are termed adipose-derived stem cells (ASCs). Subcutaneous adipose tissue has been attracting attention as a new source of tissue stem cell replacing the bone marrow because tissue collection in a large quantity is possible, the rate of cells with multipotency is high, mass culture is easy, and cells have functions equivalent to bone marrow-derived mesenchymal stem cells. Ishikawa et al. compared ASCs with those from other cell sources (ES, iPS, and bone marrow-derived stem cells), and observed that ASCs serve as a source with both simplicity and safety for clinical application [2].

In this chapter, we describe the methods used in our laboratory for the isolation and expansion of ASCs. In addition, we present the potential application of ASCs to human regenerative medicine and comment on the progress of this approach and future trends in the field. The rapidly expanding field of basic and clinical research into ASCs biology, pathophysiology, and potential therapeutic applications promises further exciting discoveries in the near future.

\section{Isolation of adipose-derived stem cells}

There are two ASC separation methods: the manual collagenase enzymatic digestion method and the method that employs the automatic adipose-derived stem cells isolation system.

The manual separation method requires a cell processing center (CPC), which involves additional costs in terms of its establishment, management and personnel. On the other hand, the automatic adiposederived stem cells isolation system is useful for clinical application in that it does not require a CPC and enables quick autograft of ASC in an operation room. The respective methodologies and characteristics are explained below. In previous studies, we established a standard protocol for the isolation of ASCs from adipose tissue using collagenase enzymatic digestion [3]. This method was partially modified from that reported by Zuk et al. [4]. Briefly, adipose tissue was washed extensively with $20 \mathrm{~mL}$ of phosphate-buffered saline (PBS) 3 times, cut into small pieces, and the extracellular matrix was digested with $0.1 \%$ collagenase solution with shaking at $37^{\circ} \mathrm{C}$ for $40 \mathrm{~min}$. After adding medium consisting of Dulbecco's modified Eagle's medium (DMEM), $10 \%$ fetal bovine serum (FBS), and $1 \%$ penicillin, it was centrifuged at 1,500 rpm for 3 min and washed using DMEM with FBS 3 times.
Since prolonged digestion with collagenase and insufficient washing reduce cell viability and influence proliferation and differentiation, these processes should be carefully performed. The supernatant was discarded and the pellet resuspended and filtered through a $100 \mu \mathrm{m}$ cell strainer to remove undigested tissue fragments. The cells were pelleted and then resuspended in cell culture medium, consisting of DMEM, $10 \% \mathrm{FBS}$, and $1 \%$ penicillin. The adhered ASCs were maintained until passage 3 in the medium, and nearly all formed fibroblast-like cells.

Mature adipocytes and cell components are precipitated in the upper and lower layers, respectively, using cell dispersion with collagenase. Cells obtained by washing the cell components in the lower layer are clinically and experimentally used as ASCs. ASCs are employed in two ways: fresh ASCs are directly used or adherent ASCs, selected by culture in a petri dish, are used.

Human adipose tissues used for ASC extraction may be either lipoaspirates or fat pieces, minced from a fat block. Abdominal fat is often applied.

Various devices have recently been developed to extract and transplant fresh ASCs from adipose tissue without a culture process. These are roughly divided into automatic, semi-automatic, and manual types. We consider that the automatic type is advantageous because it performs processes from cell isolation to concentration aseptically and automatically. In this report, we introduce Celution $800 / C R S$ (Cytori Therapeutics, San Diego, CA) and Tissue Genesis Icellator Cell Isolation System ${ }^{\bullet}$ (Tissue Genesis, Inc., Honolulu, Hawaii). Each system isolates cells using an exclusive enzyme and disposable kit.

Celution ${ }^{\circ} 800 /$ CRS is an automatic system characterized by easy separation, a closed system, no possibility of air contamination, and

*Corresponding author: Natsuko Kakudo, M.D., PhD, Department of Plastic and Reconstructive Surgery, Kansai Medical University, 10-15 Fumizono, Moriguchi 570-8506, Japan, Tel: +81-6-6992-1001; Fax: +81-6-6997-0628; E-mail:kakudon@hirakata.kmu.ac.jp

Received February 21, 2014; Accepted May 08, 2014; Published May 10, 2014

Citation: Kakudo N, Morimoto N, Ogawa T, Kusumoto K (2014) Potential of Adipose-Derived Stem Cells for Regeneration Medicine: Clinical Application and Usefulness of Fat Grafting. J Stem Cell Res Ther 4: 204. doi:10.4172/2157 7633.1000204

Copyright: @ 2014 Kakudo N, et al. This is an open-access article distributed unde the terms of the Creative Commons Attribution License, which permits unrestricted use, distribution, and reproduction in any medium, provided the original author and source are credited. 
mobility due to being fitted with wheels. It can process $100-360 \mathrm{~mL}$ of aspirated adipose tissue per operation. The Icellator ${ }^{\circledR}$ is also an automatic system characterized by easy separation, a closed system, and no possibility of air contamination. The major difference from Celution ${ }^{\circ} 800 /$ CRS is its capacity for processing aspirated adipose tissue per operation: $15-60 \mathrm{~mL}$.

\section{Cell surface marker of adipose-derived stem cells}

Researchers have various opinions about cell surface markers of ASCs, and no consensus has been reached. The discoverers of ASCs, Zuk et al., reported that ASCs expressed CD29, CD44, CD71, CD90, CD105/SH2, and SH3, but showed no CD31, CD34, or CD45 expression. Moreover, they reported that flow cytometry of ASCs confirmed the expression of CD13, whereas no expression of CD14, 16, $56,62 \mathrm{e}$, or 104 was detected [1].

In contrast, Yoshimura et al. reported that fresh ASCs exhibited the phenotype of CD31 (-), CD34 (+), CD45 (-), CD90 (+), CD105 (-), and CD146 (-), and strongly expressed CD105 in culture [5]. Changes in ASCs markers due to the culture conditions and number of passages have been pointed out as causes of this inconsistency. The expression of CD34, CD90, CD73, CD44, and CD29 changes during the cell passages [6].

Lin et al. [7] reported that cells isolated using Celution ${ }^{\circ} 800 / C R S$ were comprised of fresh ASCs and peripheral blood stem cells (EC/ EPC) accounting for $8.0 \pm 5.9 \%$, vascular smooth muscle cells (VSMC/ pericytes) for $8.0 \pm 6.0 \%$, hematopoietic stem cells (HSC) for $4.6 \pm$ $1.3 \%$, white blood cells for $7.6 \pm 8.6 \%$, and lymphocytes for $19.0 \pm$ $14.0 \%$. On the other hand, it is reported that ASCs isolated using Tissue Genesis Cell Isolation System were composed of leukocytes (CD45+), vascular endothelial cells (CD31+, CD34+, CD45-), adipose-derived stem cells, and other cells (CD31-, CD34+, CD45- ) [8]. As an issue for future research, it will be necessary to clarify differences in cell surface markers between cultured and fresh ASC, and identify markers characteristic of ASCs.

\section{Differentiation and angiogenesis-promoting effect of adipose-derived stem cells}

Various studies have clarified that human ASCs differentiate into fat, bone, cartilage, skeletal and heart muscles, blood vessels, and liver [9-17]. In addition, these progenitor cells have been suggested to be able to release multiple angiogenic growth factors and cytokines/ chemokines, including vascular endothelial growth factor (VEGF), hepatocyte growth factor (HGF), and chemokine stromal cell-derived factor-1 (SDF-1). Murohara et al. [18] reported that ASCs transplanted in ischemic regions exhibited a local angiogenic growth-promoting effect compared to angiogenesis in a group without treatment, and angiogenesis may have been promoted by angiogenic growth factors and cytokines/chemokines released by ASCs themselves, in addition to direct differentiation of ASCs into blood vessels. Further research is required because angiogenesis plays an important role in tissue regeneration.

\section{Transcriptome and proteome of adipose-derived stem cells}

Independent laboratories have conducted gene microarray studies to analyze the transcriptomes of undifferentiated human ASCs and bone-marrow-derived mesenchymal stem cells. An analysis of a panel of 28 genes showed no significant differences in gene expression between the 2 cell types [19]. Furthermore, a more comprehensive comparison has determined that human ASCs and bone-marrow- derived mesenchymal stem cells share a common transcriptome [20]. In another study, the correlation coefficient for the transcriptomes of ASCs and bone-marrow-derived mesenchymal stem cells derived from multiple donors was approximately 50\%, whereas the average correlation coefficient between individual donors within the ASCs and bone-marrow-derived mesenchymal stem cells was 71 and $64 \%$, respectively [21]. In addition, ASCs and bone-marrow-derived mesenchymal stem cells from both humans and monkeys express common stem cell-associated gene markers, including Oct4, Rex1, and Sox2 [22]. These data based on mRNA analysis suggest that ASCs and bone-marrow-derived mesenchymal stem cells show distinct but similar expression profiles.

Proteomic analysis using two-dimensional electrophoresis of the whole cell extract of ASCs and bone-marrow-derived mesenchymal stem cells was performed by the same group, and showed that $23 \%$ of proteins were expressed specifically in either one or the other bonemarrow-derived mesenchymal stem cell population: $18 \%$ of total proteins were found to be differentially expressed between the two cell types [23].

\section{Clinical use of adipose-derived stem cells for fat grafting}

The fat grafting method was considered to have problems in terms of take and reliability, but this method also has superiorities such as invasion and flexibility. And as the fat grafting method has improved recently in terms of its effectiveness and significance, its cases of operation has been continuously on the rise. Nonetheless, one problem associated with this method is that adipose tissue is absorbed, making its take rate after the grafting low. Since sucked adipose tissue, which is used for grafting, contains fewer blood vessels and ASCs as compared to normal adipose tissue, efforts have been underway to improve the grafting effects by adding fresh ASCs separated from additionally collected adipose tissue (ASC-enriched fat grafting). Yosimura et al. reported that the augumentation effects of ASC-enriched fat grafting were superior to those of conventional autologous fat grafting that the investigators had previously performed [24]. They also fat grafting with ASCs o with facial lipoatrophy due to lupus profundus or ParryRomberg syndrome [25]. Pérez-Cano et al. reported that ASCs are most frequently used for ASC-enriched fat grafts. Sixty-seven patients with partial mastectomy defects of the breast received ASC-enriched fat grafts using the Celution system, and were followed up for one year. Of these patients, 50 were satisfied with their outcomes, and none experienced local cancer recurrence [26]. ASC-enriched fat grafts were applied to facial rejuvenation, facial lipodystrophy, cosmetic augmentation of breasts, and reconstruction after mastectomy of the breast using the Tissue Genesis Cell Isolation System [8]. They performed ASC-enriched fat grafts for 42 patients, with satisfactory and no serious side-effects. The study revealed that ASC-enriched fat grafts show safety and efficacy.

As explained above, as the amount of sucked adipose tissue that Celution $800 / C R S$ can process at a time is $100-400 \mathrm{~mL}$, the minimum amount of liposuction should be $100 \mathrm{~mL}$. In contrast, the processing capacity of The Icellator is $15-60 \mathrm{~mL}$, and it can therefore separate ASCs from a small amount of adipose tissue. It is desirable to select an appropriate device for each case because the amount of liposuction needed depends on the amount of adipose tissue to be grafted as well as the BMI of the patient.

\section{Clinical use of adipose-derived stem cells for various diseases}

ASCs have recently been investigated in clinical trials in patients with various diseases, besides breast reconstruction. Lendeckel et al. 
Citation: Kakudo N, Morimoto N, Ogawa T, Kusumoto K (2014) Potential of Adipose-Derived Stem Cells for Regeneration Medicine: Clinical Application and Usefulness of Fat Grafting. J Stem Cell Res Ther 4: 204. doi:10.4172/2157-7633.1000204

reported that autologous ASCs and fibrin glue with bone grafts were effective for widespread calvarial defects [27]. Alvarez PD et al. [28] reported that the bronchoscopic injection of ASCs was effective for tracheomediastinal fistula. Houtgraaf et al. [29] reported that ASCs were effective for the treatment of patients with ST-segment elevation myocardial infarction. Trivedi et al. [30] reported that ASCs transfused with unfractionated cultured bone marrow were effective in insulin openic DM patients. Garcia-Olmo et al. reported that ASCs with fibrin glue were effective for patients with complex perianal fistulas [31]. Fang et al. [32] reported that ASCs were effective for steroid-refractory acute graft-versus-host disease. Further basic experimental studies with standardized protocols and larger randomized trials need to be performed to ensure the safety and efficacy of ASCs for human use.

\section{References}

1. Zuk PA, Zhu M, Ashjian P, De Ugarte DA, Huang JI, et al. (2002) Human adipose tissue is a source of multipotent stem cells. Mol Biol Cell 13(12): 42794295.[PubMed]

2. Ishikawa T, Banas A, Hagiwara K, Iwaguro H, Ochiya T (2010) Stem cells for hepatic regeneration: the role of adipose tissue derived mesenchymal stem cells. Curr Stem Cell Res Ther 5(2): 182-189.[PubMed]

3. Kakudo N, Shimotsuma A, Kusumoto K (2007) Fibroblast growth factor-2 stimulates adipogenic differentiation of human adipose-derived stem cells. Biochem Biophys Res Commun 359(2): 239-244.[PubMed]

4. Zuk PA, Zhu M, Mizuno H, Huang J, Futrell JW, et al. (2001) Multilineage cells from human adipose tissue: implications for cell-based therapies. Tissu Eng 7(2): 211-228.[PubMed]

5. Yoshimura K, Shigeura T, Matsumoto D, Sato T, Takaki Y, et al. (2006) Characterization of freshly isolated and cultured cells derived from the fatty and fluid portions of liposuction aspirates. J Cell Physiol 208(1): 64-76.[PubMed]

6. Mitchell JB, Mclntosh K, Zvonic S, Garrett S, Floyd ZE, et al. (2006) Immunophenotype of human adipose-derived cells: temporal changes in stromal-associated and stem cell-associated markers. Stem Cells 24(2): 376385.[PubMed]

7. Lin K, Matsubara Y, Masuda Y, Togashi K, Ohno T, et al. (2008) Characterization of adipose tissue-derived cells isolated with the Celution system. Cytotherapy 10(4): 417-426.[PubMed]

8. Doi K, Tanaka S, lida H, Eto H, Kato H, et al. (2012) Stromal vascular fraction isolated from lipo-aspirates using an automated processing system: bench and bed analysis. J Tissue Eng Regen Med 7(11): 864-870.[PubMed]

9. Dragoo JL, Samimi B, Zhu M, Hame SL, Thomas BJ, et al. (2003) Tissueengineered cartilage and bone using stem cells from human infrapatellar fat pads. J Bone Joint Surg Br 85(5): 740-747.[PubMed]

10. Cowan CM, Shi YY, Aalami OO, Chou YF, Mari C, et al. (2004) Adipose-derived adult stromal cells heal critical-size mouse calvarial defects. Nat Biotechnol 22(5): 560-567.[PubMed]

11. Erickson GR, Gimble JM, Franklin DM, Rice HE, Awad H, et al. (2002) Chondrogenic potential of adipose tissue-derived stromal cells in vitro and in vivo. Biochem Biophys Res Commun 290(2): 763-769.[PubMed]

12. Mizuno H, Zuk PA, Zhu M, Lorenz HP, Benhaim P, et al. (2002) Myogenic differentiation by human processed lipoaspirate cells. Plast Reconstr Surg 109(1): 199-209; discussion 210-191.[PubMed]

13. Rodriguez AM, Pisani D, Dechesne CA, Turc-Carel C, Kurzenne JY, et al. (2005) Transplantation of a multipotent cell population from human adipose tissue induces dystrophin expression in the immunocompetent $\mathrm{mdx}$ mouse. $\mathrm{J}$ Exp Med 201(9): 1397-1405.[PubMed]

14. Planat-Benard V, Menard C, Andre M, Puceat M, Perez A, et al. (2004) Spontaneous cardiomyocyte differentiation from adipose tissue stroma cells. Circ Res 94(2): 223-229.[PubMed]

15. Safford KM, Hicok KC, Safford SD, Halvorsen YD, Wilkison WO, et al. (2002) Neurogenic differentiation of murine and human adipose-derived stromal cells. Biochem Biophys Res Commun 294: 371-379.[PubMed]
16. Planat-Benard V Silvestre JS, Cousin B, Andre M, Nibbelink M, et al. (2004) Plasticity of human adipose lineage cells toward endothelial cells: physiological and therapeutic perspectives. Circulation 109(5): 656-663.[PubMed]

17. Miranville A, Heeschen C, Sengenes C, Curat CA, Busse R, et al. (2004) Improvement of postnatal neovascularization by human adipose tissue-derived stem cells. Circulation 110(3): 349-355.[PubMed]

18. Murohara T, Shintani S, Kondo K (2009) Autologous adipose-derived regenerative cells for therapeutic angiogenesis. Curr Pharm Des 15(24): 2784 2790.[PubMed]

19. Winter A, Breit S, Parsch D, Benz K, Steck E, et al. (2003) Cartilage-like gene expression in differentiated human stem cell spheroids: a comparison of bone marrow-derived and adipose tissue-derived stromal cells. Arthritis Rheum 48(2): 418-429.[PubMed]

20. Fraser JK, Wulur I, Alfonso Z, Hedrick MH (2006) Fat tissue: an underappreciated source of stem cells for biotechnology. Trends Biotechnol 24(4): 150-154. [PubMed]

21. Liu TM, Martina M, Hutmacher DW, Hui JH, Lee EH, et al. (2007) Identification of common pathways mediating differentiation of bone marrow- and adipose tissue-derived human mesenchymal stem cells into three mesenchymal lineages. Stem Cells 25(3): 750-760.[PubMed]

22. Izadpanah R, Trygg C, Patel B, Kriedt C, Dufour J, et al. (2006) Biologic properties of mesenchymal stem cells derived from bone marrow and adipose tissue. J Cell Biochem 99(5): 1285-1297.[PubMed]

23. Noël D, Caton D, Roche S, Bony C, Lehmann S, et al. (2008) Cell specific differences between human adipose-derived and mesenchymal-stromal cells despite similar differentiation potentials. Exp Cell Res 314(7): 1575-1584. [PubMed]

24. Yoshimura K, Sato K, Aoi N, Kurita M, Hirohi T, et al. (2008) Cell-assisted lipotransfer for cosmetic breast augmentation: supportive use of adiposederived stem/stromal cells. Aesthetic plastic surgery 32(1): 48-55; discussion 56-57.[PubMed]

25. Yoshimura K, Sato K, Aoi N, Kurita M, Inoue K, et al. (2008) Cell-assisted lipotransfer for facial lipoatrophy: efficacy of clinical use of adipose-derived stem cells. Dermatol Surg 34(9): 1178-1185.[PubMed]

26. Perez-Cano R, Vranckx JJ, Lasso JM, Calabrese C, Merck B, et al. (2012) Prospective trial of adipose-derived regenerative cell (ADRC)-enriched fat grafting for partial mastectomy defects: the RESTORE-2 trial. Eur J Surg Oncol 38(5): 382-389.[PubMed]

27. Lendeckel S, Jodicke A, Christophis P, Heidinger K, Wolff J, et al. (2004) Autologous stem cells (adipose) and fibrin glue used to treat widespread traumatic calvarial defects: case report. J Craniomaxillofac Surg 32(6): 370 373.[PubMed]

28. Ivarez PD, Garcia-Arranz M, Georgiev-Hristov T, Garcia-Olmo D (2008) A new bronchoscopic treatment of tracheomediastinal fistula using autologous adipose-derived stem cells. Thorax 63(4): 374-376.[PubMed]

29. Houtgraaf JH, den Dekker WK, van Dalen BM, Springeling T, de Jong R, et al (2012) First experience in humans using adipose tissue-derived regenerative cells in the treatment of patients with ST-segment elevation myocardial infarction. J Am Coll Cardiol 59(5): 539-540.[PubMed]

30. Trivedi HL, Vanikar AV, Thakker U, Firoze A, Dave SD, et al. (2008) Human adipose tissue-derived mesenchymal stem cells combined with hematopoietic stem cell transplantation synthesize insulin. Transplant Proc 40(4): 1135-1139. [PubMed]

31. Garcia-Olmo D, Garcia-Arranz M, Herreros D (2008) Expanded adiposederived stem cells for the treatment of complex perianal fistula including Crohn's disease. Expert Opin Biol Ther 8(9): 1417-1423.[PubMed]

32. Fang B, Song Y, Liao L, Zhang Y, Zhao RC (2007) Favorable response to human adipose tissue-derived mesenchymal stem cells in steroid-refractory acute graft-versus-host disease. Transplant Proc 39(10): 3358-3362.[PubMed] 